\title{
Ethical Concepts in Norman Bryson's Essay on the Dutch Painting
}

\author{
T. V. Lunyova
}

Kyiv National Linguistic University, Kyiv, Ukraine

Corresponding author. E-mail: lunyovat@gmail.com

Paper received 11.11.19; Accepted for publication 23.10.19.

\section{https://doi.org/10.31174/SEND-Ph2019-212VII63-07}

\begin{abstract}
The article examines the ethical concepts verbalized in Norman Bryson's essay on the Dutch painting. It reveals the specific features of these concepts as well as their distinctive functions in the essay. It has been determined that the ethical concepts in the essay belong to the thick ethical concepts and as such possess both the evaluative and the descriptive aspects. Depending on their significance in the interpretative ekphrasis in the essay, these concepts form a certain hierarchy with the concepts ABUNDANCE, LUXURY, and AFFLUENCE occupying the top. The main functions of the ethical concepts actualized in the essay is to reveal the need to take the historic approach to the picture interpretation as well as to provide detailed interpretations of particular artworks and of the common trends in the Dutch painting of the $17^{\text {th }}$ century.
\end{abstract}

Keywords: cognitive-discursive paradigm, discourse on painting, essay, ekphrasis, ethical concept.

Introduction. This study is methodologically grounded in the cognitive-discursive paradigm which with its overarching aim of disclosing both the general principles and the details of the interrelationships between language and thought has brought under the linguistic study a wide range of specific verbal phenomena. Essays on the art of painting can be viewed as a specific type of discourse where the verbal and the visual come into an intricate interplay to constitute a complex semantic whole. Essays on painting include pictures descriptions as their constitutive feature. These verbal descriptions of visual artworks are in the focus of the current study.

Literature review. There is a strong and growing tradition of analysing verbal descriptions of the visual works of art in terms of ekphrasis. The term ekphrasis is most generally understood as "the verbal representation of visual representation" [4] or as "the verbal representation of graphic representation" [3, p. 299]. While the notion of ekphrasis has a robust tradition to be used for the analysis of the verbal descriptions of pictures in poetry, the application of this notion to the studies of other texts on art, such as art criticism or art history is a relatively new development. James Heffernan recognized the need of ekphrasis to "open itself up to the vast body of writing about pictures which is commonly known as art criticism" [3, p. 304]. Peter Wagner expressed a similar idea that the term ekphrasis can be used in the discussion of criticism and art history [7, p. 13].

Since every painting is a complex phenomenon with its material form and its implied meaning, a verbal description of an artwork can relate to its different aspects. The theoretical framework to capture this fact may be found in the study of Elena Yacenko who suggests distinguishing between descriptive and interpretative ekphrasis [8]. As the researcher explains, interpretative ekphrasis aims at discovering the deep symbolic meaning of an artwork; such a description provides detailed explanations what the painted image should mean [8].

Aspiring to discover the meaning of a piece of visual art, interpretative ekphrasis can rely upon the verbalized concepts which represent the moral values and attitudes. Such concepts are called ethical concepts. In the cognitive studies, an ethical concept is viewed as an element of the individual and group consciousness which includes cognition, knowledge and motivation to act in a certain way [5, p. 4], as a representation of moral norms in human consciousness [2, p. 10]. Having different structures and functioning in different ways, ethical concepts can be subdivided into thin and thick ones [6]. The thin ethical concepts can be illustrated with the examples of RIGHT, BAD, PERMISSIBLE or OUGHT and include only evaluation while the thick ethical concepts "involve both evaluation and non-evaluative description" [6].

The insufficient scholarship on the interpretative ekphrasis in essays on visual art as well as ethical concepts in this type of discourse necessitates the current study.

The aim of the paper is to reveal the peculiarities of the ethical concepts employed by Norman Bryson in his essay on the Dutch painting and to determine the characteristic features of functioning of these concepts in the essay.

Material and methods. The material of this study is the contexts of the verbalisation of the ethical concepts in Norman Bryson's essay "Abundance" [1, p. 96-135]. The methods used are the methods developed within the cognitive-discursive paradigm, in particular conceptual analysis and discursive analysis.

Results and discussion. The crucial role of the ethical concepts in Bryson's essay on the Dutch painting is signalled by the fact that such a concept - ABUNDANCE - is chosen to act as the title of the essay. As an any abstract concept, ABUNDANCE is open to a wide range of subjective interpretations and in order to serve as a means of clarification of a painting's meaning, this concept should be explicitly elucidated. This is exactly what happens in the essay as Bryson takes the first three pages to illuminate the meaning of the concept ABUNDANCE. The domain of ETHICS where the concept ABUNDANCE is placed in the essay is evoked in the first paragraph of the text with the help of the lexeme ethics, e.g.: "But with industrialisation the old discourse of ethics, which measures wealth according to moral conduct, is obliged to co-exist alongside a newer perception which substitutes for the term 'luxury' the term 'affluence'.' [1, p. 96]. The domain ETHICS is consistently actualized through the essay with the help of a range of linguistic means, in particular: the lexeme ethics (e.g.: "As a result, the ancient regime's understanding of luxury is bound up with a discourse that measures sufficiency and insufficiency by a standard of ethics. " [1, p. 96]) and ethical (e.g.: "... centrality of the ethical discourse on wealth ..." [1, p. 99]), the lexeme virtue (e.g.: "... it is as though the affluence of the house could be justified only of domestic virtue kept strict pace with prosperity. " [1, p. 111]), the lexeme moral (e.g.: " ... measures wealth according to moral conduct ..." [1, p. 96]), the lexeme morals (e.g.: "Affluence assumes that expenditure is not a matter of morals but of style." [1, p. 96]), the lexeme morality (e.g.: “... the ancient discourses on wealth which interpreted riches through the categories of morality ... " [1, p. 99]), and the moral term psychomache which gets contextual explanation (e.g.: " 'Luxury' 
can never shed its ties to its medieval past, to the idea of psychomache, the battle of the soul against the deadly sins, luxuria, superbia, vanagloria, voluptas, cupiditas. " [1, p. 96]).

The concept ABUNDANCE verbalized in Bryson's essay on the Dutch painting is a thick ethical concept. Bryson does not spare the essay space to explain its meaning. First of all, he suggests a need of a historical approach to the interpretation of the meaning of the concept ABUNDANCE which, as Bryson reveals has changed its evaluative component since the Industrial Revolution: "In the industrialised countries we are used to overproduction. We have made societies of abundance since at least the time of the Industrial Revolution. So many generations have passed in which conditions of oversupply have prevailed that it requires a certain cultural dislocation to think back to the period when overabundance was somethings historically new - or to think outwards towards the non-industrialised or semi-industrialised countries of the Third World today. Perhaps one can draw a distinction between abundance before and after industrialisation. " [1, p. 96]. The underlined parts of the quote work together to make the differences in the attitude to abundance as a phenomenon clear. Besides highlighting such a difference, the quoted above passage actualises the two concepts contextually closely related with the concept ABUNDANCE: OVERPRODUCTION ("In the industrialised countries we are used to overproduction") and OVERSUPPLY ("So many generations have passed in which conditions of oversupply..."). Furthermore, the following contextually related concepts are actualized in the close context: SURPLUS (e.g.: “... incapable of generating the surplus necessary to finance the development of industry ..." [1, p. 96]), WEALTH (e.g.: "surplus wealth" [1, p. 96]), LUXURY (e.g.: "As a result, the ancient regime's understanding of luxury is bound up with a discourse that measures sufficiency and insufficiency by a standard of ethics.” [1, p. 96]), AFFLUENCE (e.g.: “Affluence assumes that expenditure is not a matter of morals but of style." [1, p. 96]) with the LUXURY and AFFLUENCE being contextually opposed as representing different historical attitudes to the phenomenon of abundance, e.g.: "But with industrialisation the old discourse of ethics, which measures wealth according to moral conduct, is obliged to co-exist alongside a newer perception which substitutes for the term 'luxury' the term 'affluence,." [1, p. 96]. Overall, the following conceptual structure is created in the essay: ABUNDANCE BEFORE THE INDUSTRIAL REVOLUTION = LUXURY:: ABUNDANCE AFTER THE INDUSTRIAL REVOLUTION = AFFLUENCE.

In addition to these descriptive representations of the concept ABUNDANCE, the essay provides the clear statement about the evaluative component of this concept. The text reveals that before the Industrial Revolution the concept ABUNDANCE was viewed as LUXURY and had a negative evaluative component, e.g.: "In pre- or proto-industrial societies, luxury is inseparable from ideas of prodigality and waste. $"$ [1, p. 96]. In this quote the lexemes prodigality and waste actualize the negative attitude to abundance. In contrast, after the Industrial Revolution the concept ABUNDANCE viewed as AFFLUENCE acquired the positive evaluative component, e.g.: "Affluence assumes that expenditure is not a matter of morals but of style. It proposes that for individuals, and for society at large, the utilisation of wealth in the pursuit of pleasure works to the economic good of all." [1, p. 96-97]. In this quote the lexeme good actualises the positive evalua- tive component. The opposition between ABUNDANCE BEFORE THE INDUSTRIAL REVOLUTION and ABUNDANCE AFTER THE INDUSTRIAL REVOLUTION is further clarified with the opposition between ETHICAL and AESTHETIC, e.g.: "Industrialisation makes it impossible any longer to distinguish with certainty between luxury and necessity, and the old polarity of dearth and surfeit dissolves. Aesthetic culture, which now takes up the slack from ethical culture, resolves the problem of overproduction by indicating general models for managing the superabundance of goods." [1, p. 97].

Thus at this point in his essay Bryson has explained the descriptive component of the concept ABUNDANCE through relating it with the concepts LUXURY and AFFLUENCE and revealed the evaluative components of the concept ABUNDANCE through actualizing the thin ethical concepts BAD and GOOD. The following text dwells on these explanations as Bryson offers an interpretation of the Dutch paintings belonging to the period of the Netherlands economic ascendancy in 1608-1660-s [1, p. 98].

Bryson continues with clarifying the understanding of the concept ABUNDANCE by the Dutch of the $17^{\text {th }}$ century, e.g.: "Those traditions concerning the uses of surplus wealth which it [Dutch society in the seventeenth century] did possess dated from its immediate past, the ancient discourse on wealth which interpreted riches through the categories of morality; perhaps it is the absence of alternatives that accounts for the persistence and centrality of the ethical discourse on wealth through to the close of the period of Dutch economic ascendancy, and not lest in painting. "' [1, p. 99]. The underlined parts of the quote actualize the domain of ETHICS and the concepts SURPLUS, WEALTH. The verbal expression the ethical discourse on wealth evokes the concept BAD as an evaluative concept since the previous text made the connection between pre-industrial ethical attitude to the phenomenon of wealth clear.

The first picture analysed in the essay is Pieter Brueghel the Elder's The Battle between Carnival and Lent. Dwelling upon the provided conceptual clarification, Bryson interprets the meaning of this picture as such that epitomises the historical predicament of the Dutch society, i.e. the continuous usage of the ethical approach to dealing with the abundance, e.g.: "One can see why the ethical approach to the phenomena of need and abundance could be so persuasive in this agrarian world..." [1, p. 100]. Through interpreting the meaning of the picture, Bryson elucidates that the concept ABUNDANCE in the perception of the Dutch of the $17^{\text {th }}$ century was closely connected with the ideas of the ABUNDANCE OF NATURE and ABUNDANCE IN THE COMMUNITY, e.g.: "When abundance comes, it is that of the $\underline{\text { land, for the people who live from the land; a banquet of the }}$ world, rather than the affluence of private tables." [1, p. 100]. He follows by making the statement about the Dutch painting in general: "Much of the complexity in Dutch still life will come from the collision between this traditional and community-based ethic, revolving round shared wealth and poverty, and the private ethic of the individual owner of property. " [1, p. 100]. This quote objectifies the conceptual opposition COMMUNITY WEALTH:: PRIVATE WEALTH as disclosed in the essay.

Juxtaposing the descriptions of the depicted interiors in the two paintings by Pieter de Hooch dating to the 1650-s and 1670-s, Bryson provides vivid descriptive erkphrases [1, p. 102-104] which highlight how the pictures reflected the 
changes in the economic life of the Dutch society. Bryson uses this explanation to ground his interpretative ekphrasis of the Dutch still life paintings, e.g.: "Dutch still life painting is a dialogue between this newly affluent society and its material possessions. " [1, p. 104]. This statement allows Bryson to create impressively illuminating interpretative erkphrases of the Dutch flower paintings [1, p. 104-110]. In particular, he states that "The flower pictures reveal a good deal about the ways in which the Dutch viewed and understood the affluence their culture was able to produce. The feeling is evident that not much is owed to nature. [...] The labour of horticulture, the forcing of varieties, and then the long hours of the painter's craftsmanship - it is as if the value of the flowers were created by human effort alone. Production, production! " [1, p. 109110]. This quote demonstrates the shift in the conceptualisation of abundance by the Dutch from ABUNDANCE OF NATURE to ABUNDANCE OF HUMAN PRODUCTION.

The meanings of the Dutch still life pictures are interpreted by Bryson as attempts to provide to the society the solution to the problem how to deal with affluence, e.g.: "Though idyllic, Claesz.' sombre still lifes reveal a certain anxiety concerning material consumption in the equation they suggest between virtue and modesty of means. " [1, p. 113]. In this context the lexeme virtue actualises the domain of ETHICS and the word combination material consumption evokes the concept AFFLUENCE. With his interpretative ekphrasis Bryson demonstrates that the Dutch still life painters tried to cope with the changes of the evaluation attached to the affluence, e.g.: " $\underline{T h e}$ virtues of bare sufficiency: Claesz.' Paintings insist on them, even at the cost of somewhat forcing the image into the mould of noble calm. They occupy the admonitory or censorious end of the Dutch still life spectrum, and represent at any rate one solution to the problem of affluence: absolute refusal of material excess." " 1, p. 115]. In this quote the concept AFFLUENCE is actualised together with the concept EXCESS with which it has a strong semantic correlation in the context. The evaluative component BAD is objectified through the verbal expression absolute refusal of material excess.

The provided in the essay fine analysis of the concept AFFLUENCE allowed Bryson to notice important regular trends in the Dutch paintings, e.g.: "Interestingly, the degree of disorder seems to increase in proportion to the level of affluence the table indicates as whole. " [1, p. 121]. In this quote the negative evaluative component of the concept AFFLUENCE (verbalized by the lexeme affluence) is objectified with the help of the lexeme disorder. The provided interpretative ekphrasis illuminates the symbolic role of the depicted disorder as the criticism on affluence.

Close to the end of his essay, Bryson comes to the conclusion that the concept AFFLUENCE as represented in the Dutch still life paintings retains close semantic links with the concept LUXURY as it was understood at the period before the Industrial revolution, e.g.: "In Dutch still life affluence is rarely presented through a neutral inventory of goods, but is coded through discourses that impose on abundance their own principles of intelligibility and control, and ensure that 'affluence' remains in the orbit of 'luxury' in its older sense.", [1, p. 131]. And the conclusion itself is an interpretative ekphrasis which employs the concept AFFLUENCE, e.g.: "They [the Dutch painters of still life] know that in mercantile society, awareness of class and of the thousand degrees of affluence is as much a part of ordinary and everyday experience as any of the creaturely pleasures of eating and drinking..." [1, p. 135]. This quote summarises the interpretations of the Dutch paintings in the essay and highlights the role of the ethical concept AFFLUENCE in the consciousness of the Dutch painters and thus its relevance to the meanings of their pictures.

Conclusion. The ethical concepts employed by Norman Bryson in his essay on the Dutch painting are predominantly thick ethical concepts having both the evaluative and the descriptive aspects. These concepts form in the essay a certain hierarchy depending on their significance for the interpretative ekphrasis. The top of this hierarchy is occupied by the concepts ABUNDANCE, LUXURY, and AFFLUENCE, with the such concepts as OVERPRODUCTION, OVERSUPPLY, SURPLUS, and WEALTH taking the dependant position. Both the descriptive and the evaluative aspects of the key ethical concepts are presented in the essay through the construction of several conceptual oppositions. The key functions of the ethical concepts actualized in the essay are to demonstrate the need of the historical approach to the picture interpretations as well as to suggest detailed and wellgrounded interpretations of particular pictures and of the common trends in the Dutch painting of the $17^{\text {th }}$ century.

Further investigations on the ethical concepts in the essays on the visual art will help to provide more detailed understanding of the relationships between the thin and the thick verbalized ethical concepts used in interpretative ekphrases in this type of discourse.

\section{REFERENCES}

1. Bryson Norman. Looking at the Overlooked: Four Essays on Still Life Painting. London. Reaktion Books. 1990. Reprinted 2018. $102 \mathrm{p}$.

2. Dmitriyeva N.M. The Ethical conceptual sphere of the Russian linguistic world image: diachronic aspect: dissertation of the Doctor of Sciences. 10.02.01 - the Russian language. Moscow, 2017. 455 p. (in Russian: Дмитриева Н.M. Этическая концептосфера русской языковой картины мира: диахронический аспект: дис. ... д-ра филолог. наук.10.02.01 - русский язык. Москва, 2017. 455 c.).

3. Heffernan James A.W. Ekphrasis and Representation. New Literary History. 1991. 22, No. 2 (Spring). P. 297-316.

4. Mitchell W. J. T. Ekphrasis and the Other. Picture Theory. 1994. Chicago: The University of Chicago Press. Available from: http://www.rc.umd.edu/editions/shelley/medusa/mitchell.html (Accessed on 1.03.2018).

5. Mokayeva I.R. Ethical concepts in the linguistic world image (on the material of the Russian language and Karachay-Balkar language): dissertation of the Candidate of Sciences. 10.02.19 - the

theory of the language. Nalchik. 2004. 24 p. (in Russian: Мокаева И.Р. Этические концепты в языковой картине мира (на материале русского и карачаево-балкарского языков). 10.02.19теория зыка. Автореф. . .. канд. филолог. наук. Нальчик, 2004. 24 c.).

6. Väyrynen Pekka. Thick Ethical Concepts. The Stanford Encyclopedia of Philosophy (Summer 2019 Edition), Edward N. Zalta (ed.), Available from: https://plato.stanford.edu/archives/sum2019/entries/thick-ethical-concepts/ (Accessed on 10.10.2019).

7. Wagner Peter. Introduction: Ekphrasis, Iconotexts, and Intermediality - the State(s) of Art(s). Wagner Peter (ed.) Icons - Texts Iconotexts: Essays on Ekphrasis and Intermediality. Berlin and New York: de Gruyter, 1996. P. 1-42.

8. Yacenko Elena. "Poets, you should love painting..." Ekphrasis as a poetic and worldview model. Philosophical Questions. 2011. № 11. P. 47-58 (In Russian: Яценко Е. В. «Любите живопись, поэты...». Экфрасис как художественно-мировоззренческая модель. Вопросы философии. 2011. № 11. С. 47-58). 